\title{
Article \\ Comparative Study of Chemical Composition and Antioxidant Activity of Essential Oils and Crude Extracts of Four Characteristic Zingiberaceae Herbs
}

\author{
Milena Ivanović (D), Kaja Makoter and Maša Islamčević Razboršek *
}

check for

updates

Citation: Ivanović, M.; Makoter, K.; Islamčević Razboršek, M. Comparative Study of Chemical Composition and Antioxidant Activity of Essential Oils and Crude Extracts of Four Characteristic Zingiberaceae Herbs. Plants 2021, 10, 501. https://doi.org/10.3390/ plants10030501

Academic Editor: Iztok Jože Košir

Received: 15 February 2021

Accepted: 3 March 2021

Published: 8 March 2021

Publisher's Note: MDPI stays neutral with regard to jurisdictional claims in published maps and institutional affiliations.

Copyright: (C) 2021 by the authors. Licensee MDPI, Basel, Switzerland. This article is an open access article distributed under the terms and conditions of the Creative Commons Attribution (CC BY) license (https:// creativecommons.org/licenses/by/ $4.0 /)$.
Faculty of Chemistry and Chemical Engineering, University of Maribor, Smetanova ulica 17, SI-2000 Maribor, Slovenia; milena.ivanovic@um.si (M.I.); kaja.makoter@student.um.si (K.M.)

* Correspondence: masa.islamcevic@um.si; Tel.: +386-2-22-94-437

\begin{abstract}
The ginger family (Zingiberaceae) includes plants that are known worldwide to have a distinctive smell and taste, which are often used as spices in the kitchen, but also in various industries (pharmaceutical, medical, and cosmetic) due to their proven biological activity. The aim of this study was to investigate and compare the chemical composition and antioxidant activity (AA) of essential oils (EOs) of four characteristic ginger species: Elettaria cardamomum L. Maton (cardamom), Curcuma Longa L. (turmeric), Zingiber Officinale Roscoe (ginger), and Alpinia Officinarum Hance (galangal). Furthermore, the total phenolic content (TPC) and AA of crude extracts obtained after using ultrasound-assisted extraction (UAE) and different extraction solvents (80\% ethanol, $80 \%$ methanol and water) were evaluated. A total of 87 different chemical components were determined by GC-MS/MS in the EOs obtained after hydrodistillation, 14 of which were identified in varying amounts in all EOs. The major compounds found in cardamom, turmeric, ginger, and galangal were $\alpha$-terpinyl acetate $(40.70 \%), \beta$-turmerone $(25.77 \%), \alpha$-zingiberene $(22.69 \%)$ and 1,8-cineol $(42.71 \%)$, respectively. In general, $80 \%$ ethanol was found to be the most effective extracting solvent for the bioactivities of the investigated species from the Zingiberaceae family. Among the crude extracts, ethanolic extract of galangal showed the highest TPC value $\left(63.01 \pm 1.06 \mathrm{mg} \mathrm{GA} \mathrm{g}^{-1} \mathrm{DW}\right)$, while the lowest TPC content was found in cardamom water extract $\left(1.04 \pm 0.29 \mathrm{mg} \mathrm{GA} \mathrm{g}^{-1} \mathrm{DW}\right)$. The AA evaluated by two different assays (ferric-reducing antioxidant power-FRAP and the scavenging activity of the cationic ABTS radical) proved that galangal rhizome is the plant with the highest antioxidant potential. In addition, no statistical difference was found between the AA of turmeric and ginger extracts, while cardamom rhizome was again inferior. In contrast to the crude extracts, the EOs resulted in significantly lower ABTS and FRAP values, with turmeric EO showing the highest AA.
\end{abstract}

Keywords: Zingiberaceae family; cardamom; turmeric; galangal; ginger; essential oils; GC-MS/MS; antioxidant activity

\section{Introduction}

The ginger family (Zingiberaceae) consists of 53 genera and about 1300 different species, mainly distributed in South and South-East Asia [1]. Many herbs from this family have found applications in various industries (food, cosmetics, perfumery, pharmacy, etc.) due to their characteristic organoleptic properties (color, taste, odor) and their diverse chemical composition [2]. Indeed, Zingiberaceae species are a rich source of various phytochemicals, from alkaloids, carbohydrates, proteins, phenolic acids, flavonoids, and diarylheptanoids $[3,4]$. In addition, ginger plants are frequently used for the production of essential oils (EOs), which are typically rich in monoterpenes and sesquiterpenes $[3,5]$. Besides their well-known use in cosmetics, cleaning products, perfumes, and aromatherapy, EOs also serve as natural preservatives due to their proven antimicrobial and antifungal properties [6-8]. However, a thorough evaluation of the chemical profile of EOs is of 
great importance to uncover potential synergistic antimicrobial activities between EO compounds, as already shown for thyme [9,10] and ginger EO [11].

Cardamom (Elettaria cardamomum L. Maton) is a spice with a characteristic rich taste and aroma, also known as "true cardamom" or "green cardamom" [3], rich in essential oils, fatty acids, pigments, proteins, cellulose, sugars, starch, silica, calcium oxalate, and minerals [12]. The content of EOs in cardamom fruits varies between $0.2-6.2 \%$, while the most dominant compounds found are 1,8-cineol (20-60\%) and $\alpha$-terpinyl acetate (20-55\%) [3]. Based on the results published so far, the cardamom fruit has potential applications as an antimicrobial, antibacterial, antioxidant, and an efficient skin-permeation agent for certain drugs [13,14], but also as bacterial inhibitor [15].

The main compounds found in the rhizome of turmeric (Curcuma longa L., curcuma) are essential oil [16,17] and curcuminoids (including curcumin, dimetoxycurcumin, and bisdimetoxycurcumin), a class of diarylheptanoids responsible for the characteristic orangeyellow color of turmeric spices, but also for their pharmaceutical properties [18]. In general, the therapeutic properties of curcuma include insecticidal, antimicrobial, antifungal, and antioxidant activity [16]. However, the results of published studies have also shown neuroprotective, hepatoprotective, cardiovascular, anti-inflammatory, antidiabetic, and anticancer effects of the turmeric extract [19-21].

The main ingredients of the ginger rhizome (Zingiber officinale Roscoe) are gingerols / shogaols and essential oil. Gingerols (characteristic compounds of the Zingiberaceae family, especially ginger) are the biologically main active components of fresh ginger, while gingerol derivatives, shogaols (dehydrated form of gingerols) are components of dried or cooked ginger [22]. Ginger is also rich in vitamins A and C, while the other compounds such as fatty acids, proteins, carbohydrates, fiber, ash, minerals (potassium, calcium, phosphorus, magnesium, iron) are present in lower amounts [23]. Recent studies have shown various pharmaceutical effects of the ginger rhizome, and the most important is the proven antidiabetic effect [24,25].

Alpinia officinarum Hance, commonly known as lesser galangal, with proven antiinflammatory, cytotoxic, thermostabilizing, lipid regulating, antioxidant, antiviral, and antimicrobial properties, is also a rich source of phenolic compounds, in particular diarylheptanoids and essential oil [26]. However, despite its proven healing effects, some research has shown that diarylheptanoids are associated with some limitations including low oral absorption, bio-distribution, and systemic bioavailability, which lead to its failure in clinic as a drug [27].

In general, it can be stated that the antioxidant and pharmaceutical properties of Zingiberaceae plants are related to their chemical composition; this is primarily due to the presence of phenolic compounds and other biologically active constituents. Various extraction methods have already been evaluated for the isolation and purification of different bioactive compound classes from ginger spices, including classical hydrodistillation $[2,5,28,29]$, extractions with supercritical fluids (supercritical $\mathrm{CO}_{2}$, supercritical water) $[22,30,31]$, ultrasound-assisted extraction [32,33], and microwave-assisted extraction [34]. Gas chromatography-mass spectrometry (GC-MS) is a commonly used method for chemical characterization of EOs $[1,29,32,35,36]$. On the other hand, the polyphenolic profile of the selected herbs was usually evaluated by high performance liquid chromatography (HPLC) using different detectors [37-39]. In general, the chemical diversity of Zingiberaceae species and the content of the individual bioactivities have already been studied. For instance, based on the study reported by Elguindy et al., the major phenolics identified in the cardamom extract were tannic acid, gallic acid, caffeic acid, and 4,5dicaffeoyl quinic acid [40]. In turmeric extracts, curcumin and its corresponding isomers, dimetoxycurcumin and bis-dimetoxycurcumin, were determined to be the major compounds in polar solvents [30]. The biological activity of ginger crude extracts is related to the presence of gingerol, turmeric, paradol, geraniol, geranial, borneol, linalool, camphene, zingerol, and zingiberone found in high concentrations [41], while Köse et al. in their study 
found flavonoids like kaempferol, apigenin, and luteolin as the most dominant compounds in galangal extracts [37].

However, to the best of our knowledge, there is no published work that systematically compares the chemical composition of the four selected Zingiberaceae herbs. Therefore, the main contribution of this work focuses on the study of the chemical composition and antioxidant activity (AA) evaluated by two different assay (ABTS and FRAP) of the essential oils of four plants, namely galangal, cardamom, turmeric, and ginger, which were extensively investigated after conventional hydrodistillation. In addition, the total phenolic content (TPC) and AA of the crude extracts were also examined. For this purpose, the plant material was processed by UAE using three different extraction solvents: $80 \%$ ethanol, $80 \%$ methanol, and water.

\section{Results and Discussion}

\subsection{Essential Oils (EOs) Composition}

The content of total extracted EOs in the selected species from the Zingiberaceae family varied from $0.29 \%$ to $3.74 \%$ of dry weight. GC-MS/MS analysis was used for the detailed analysis of EOs of the four selected plant species (cardamom fruit and rhizomes of turmeric, ginger and galangal) obtained by hydrodistillation. Consequently, GC-MS/MS analysis revealed the presence of a total of 87 different chemical structures (compounds), 14 of which were identified in varying amounts in all the EOs. All the identified compounds and their respective contents in the target plants are listed systematically in Table 1 in the order of elution from the non-polar VF-5ms capillary column.

Table 1. Chemical composition of essential oils (EOs) of four Zingiberaceae plants identified by GC-MS/MS after 3 h of hydrodistillation.

\begin{tabular}{|c|c|c|c|c|c|c|}
\hline \multirow[b]{3}{*}{ No. } & \multirow{3}{*}{ Chemical Compound } & \multicolumn{4}{|c|}{ Peak Area Percentage (\%) } & \multirow[b]{3}{*}{ Classification } \\
\hline & & Cardamom & Turmeric & Ginger & Galangal & \\
\hline & & $\begin{array}{c}\text { Elettaria } \\
\text { cardamomum } \\
\text { L. Maton }\end{array}$ & $\begin{array}{l}\text { Curcuma longa } \\
\text { L. }\end{array}$ & $\begin{array}{l}\text { Zingiber } \\
\text { officinale } \\
\text { Roscoe }\end{array}$ & $\begin{array}{c}\text { Alpinia } \\
\text { officinarum } \\
\text { Hance }\end{array}$ & \\
\hline 1 & $\begin{array}{l}\text { 4-acetyl-1-methyl-1- } \\
\text { cyclohexene }\end{array}$ & - & 0.03 & - & - & other \\
\hline 2 & $p$-acetyl toluene & - & 0.08 & - & - & other \\
\hline 3 & trans-anethole & - & 0.04 & - & 0.42 & other \\
\hline 4 & cis- $\alpha$-bergamotene & - & - & 0.11 & - & sesquiterpene \\
\hline 5 & trans- $\alpha$-bergamotene & - & 0.09 & 0.08 & 0.22 & sesquiterpene \\
\hline 6 & Borneol & - & - & 0.04 & 0.06 & monoterpene \\
\hline 7 & $\beta$-bisabolene & - & 3.04 & 7.55 & 0.38 & sesquiterpene \\
\hline 8 & Butyl isobutyrate & - & - & - & 0.34 & other \\
\hline 9 & sec-butyl isobutyrate & - & - & - & 0.19 & other \\
\hline 10 & Benzyl acetone & - & - & - & 0.14 & other \\
\hline 11 & 3-carene & - & 0.03 & - & - & monoterpene \\
\hline 12 & o-cymene & - & 0.01 & - & - & monoterpene \\
\hline 13 & $p$-cymene & 0.11 & 3.36 & 0.10 & 0.52 & monoterpene \\
\hline 14 & Camphor & - & 0.01 & 0.10 & 2.24 & monoterpene \\
\hline 15 & p-cymenol & - & 0.17 & 0.03 & 0.03 & other \\
\hline 16 & Carvone & - & 0.06 & - & 0.34 & monoterpene \\
\hline 17 & Carvacrol & - & 0.22 & - & / & monoterpene \\
\hline 18 & $\beta$-caryophyllene & - & 0.85 & 0.06 & 0.49 & sesquiterpene \\
\hline 19 & ar-curcumene & - & 11.42 & 11.63 & 0.94 & sesquiterpene \\
\hline 20 & Caryophyllene oxide & - & 0.69 & - & 0.43 & sesquiterpene \\
\hline 21 & $\begin{array}{l}\text { 1-(3-cyclopentylpropyl)- } \\
\text { 2,4-dimethylbenzene }\end{array}$ & - & 1.47 & - & - & other \\
\hline 22 & Cedrenol & - & 0.73 & - & - & sesquiterpene \\
\hline 23 & Curlone & - & 7.59 & - & - & sesquiterpene \\
\hline 24 & 1,8-cineol/eucalyptol & 33.78 & 2.01 & 2.92 & 42.71 & monoterpene \\
\hline 25 & Camphene & - & - & 5.84 & 4.58 & monoterpene \\
\hline
\end{tabular}


Table 1. Cont.

\begin{tabular}{|c|c|c|c|c|c|c|}
\hline \multirow[b]{3}{*}{ No. } & \multirow[b]{3}{*}{ Chemical Compound } & \multicolumn{4}{|c|}{ Peak Area Percentage (\%) } & \multirow[b]{3}{*}{ Classification } \\
\hline & & Cardamom & Turmeric & Ginger & Galangal & \\
\hline & & $\begin{array}{c}\text { Elettaria } \\
\text { cardamomum } \\
\text { L. Maton }\end{array}$ & $\begin{array}{c}\text { Curcuma longa } \\
\text { L. }\end{array}$ & $\begin{array}{c}\text { Zingiber } \\
\text { officinale } \\
\text { Roscoe }\end{array}$ & $\begin{array}{c}\text { Alpinia } \\
\text { officinarum } \\
\text { Hance }\end{array}$ & \\
\hline 26 & Citronellol & - & - & 0.07 & - & monoterpene \\
\hline 27 & Citronellyl acetate & - & - & 0.17 & - & monoterpene \\
\hline 28 & $\alpha$-copaene & - & - & 0.21 & 0.05 & sesquiterpene \\
\hline 29 & $\delta$-cadinene & - & - & 0.19 & 0.38 & sesquiterpene \\
\hline 30 & $\alpha$-calacorene & - & - & - & 0.63 & sesquiterpene \\
\hline 31 & $\beta$-calacorene & - & - & - & 0.08 & sesquiterpene \\
\hline 32 & Cubenol & - & - & - & 1.26 & sesquiterpene \\
\hline 33 & Cadalene & - & - & - & 0.74 & sesquiterpene \\
\hline 34 & $\begin{array}{l}\text { Dimethyl styrene } \\
\text { 4,4-dimethyl-3,4- }\end{array}$ & - & 0.05 & - & - & other \\
\hline 35 & $\begin{array}{l}\text { dihydro } \\
\text { coumarin }\end{array}$ & - & 0.63 & - & - & other \\
\hline 36 & Ethyl dihydrocinnamate & - & - & - & 0.10 & other \\
\hline 37 & $\beta$-elemene & 0.11 & - & 0.36 & - & sesquiterpene \\
\hline 38 & $\delta$-elemene & - & - & 0.03 & - & sesquiterpene \\
\hline 39 & $\alpha$-farnesene & - & - & 2.26 & - & sesquiterpene \\
\hline 40 & endo-fenchol & - & - & - & 0.03 & monoterpene \\
\hline 41 & exo-fenchol & - & - & - & 0.12 & monoterpene \\
\hline 42 & Fenchyl acetate & - & - & - & 0.55 & monoterpene \\
\hline 43 & D-germacrene & - & - & 2.79 & 1.89 & sesquiterpene \\
\hline 44 & Geranial & 0.08 & - & 0.04 & - & monoterpene \\
\hline 45 & Geraniol & 0.24 & - & - & - & monoterpene \\
\hline 46 & Geranyl acetate & 0.23 & - & 1.23 & - & monoterpene \\
\hline 47 & $\alpha$-humulene & - & 0.26 & - & 0.17 & sesquiterpene \\
\hline 48 & 2-heptanol & - & - & 0.04 & - & other \\
\hline 49 & Isobutyl isovalerate & - & - & - & 0.08 & other \\
\hline 50 & Isoamyl isovalerate & - & - & - & 0.04 & other \\
\hline 51 & $\begin{array}{l}\text { Isoamyl-2- } \\
\text { methylbutyrate }\end{array}$ & - & - & - & 0.06 & other \\
\hline 52 & Isoborneol & - & 0.01 & 1.42 & 0.60 & monoterpene \\
\hline 53 & Isobornyl acetate & - & - & 0.58 & 0.22 & monoterpene \\
\hline 54 & Isobutyl benzoate & - & - & - & 0.21 & other \\
\hline 55 & Limonene & 2.32 & 0.15 & 7.90 & 2.76 & monoterpene \\
\hline 56 & Linalool & 2.72 & 0.02 & 0.41 & 0.41 & monoterpene \\
\hline 57 & Linalyl acetate & 0.67 & - & - & - & monoterpene \\
\hline 58 & Myrcene & 0.78 & 0.05 & 0.43 & 0.20 & monoterpene \\
\hline 59 & 6-methyl-5-hepten-2-one & - & 0.01 & 0.13 & 0.41 & other \\
\hline 60 & Methyl isovalerate & - & - & - & 0.05 & other \\
\hline 61 & Neral & - & - & 0.36 & - & monoterpene \\
\hline 62 & Neryl acetate & 0.08 & - & - & - & monoterpene \\
\hline 63 & Ocimene & 0.06 & - & - & - & monoterpene \\
\hline 64 & $\alpha$-pinene & 0.98 & 0.20 & 1.83 & 3.56 & monoterpene \\
\hline 65 & $\beta$-pinene & 0.26 & 0.03 & 0.15 & 3.85 & monoterpene \\
\hline 66 & Phenethyl isobutyrate & - & - & - & 0.56 & other \\
\hline 67 & Phenethyl isovalerate & - & - & - & 0.44 & other \\
\hline 68 & $\alpha$-phellandrene & - & 1.33 & 0.40 & - & monoterpene \\
\hline 69 & $\alpha$-selinene & - & - & - & 0.72 & sesquiterpene \\
\hline 70 & $\beta$-selinene & - & - & 0.38 & 0.49 & sesquiterpene \\
\hline 71 & Sabinene & 1.82 & 0.01 & 0.08 & - & monoterpene \\
\hline 72 & $\beta$-sesquiphellandrene & - & 10.44 & 10.08 & - & sesquiterpene \\
\hline 73 & Sabinyl acetate & - & 0.20 & - & - & monoterpene \\
\hline 74 & $\alpha$-thujene & 0.14 & 0.02 & 0.01 & 0.07 & monoterpene \\
\hline 75 & $\alpha$-terpinene & 0.36 & 0.03 & 0.03 & 0.25 & monoterpene \\
\hline 76 & $\gamma$-terpinene & 0.61 & 0.03 & 0.04 & 0.31 & monoterpene \\
\hline
\end{tabular}


Table 1. Cont.

\begin{tabular}{|c|c|c|c|c|c|c|}
\hline \multirow[b]{3}{*}{ No. } & \multirow[b]{3}{*}{ Chemical Compound } & \multicolumn{4}{|c|}{ Peak Area Percentage (\%) } & \multirow[b]{3}{*}{ Classification } \\
\hline & & \multirow{2}{*}{$\begin{array}{c}\text { Cardamom } \\
\text { Elettaria } \\
\text { cardamomum } \\
\text { L. Maton }\end{array}$} & \multirow{2}{*}{$\begin{array}{c}\text { Turmeric } \\
\begin{array}{c}\text { Curcuma longa } \\
\text { L. }\end{array}\end{array}$} & \multirow{2}{*}{$\begin{array}{l}\text { Ginger } \\
\text { Zingiber } \\
\text { officinale } \\
\text { Roscoe }\end{array}$} & \multirow{2}{*}{$\begin{array}{c}\text { Galangal } \\
\text { Alpinia } \\
\text { officinarum } \\
\text { Hance }\end{array}$} & \\
\hline & & & & & & \\
\hline 77 & Terpinolene & 0.32 & 0.26 & 0.14 & 0.20 & monoterpene \\
\hline 78 & 4-terpineol & 1.85 & 0.08 & 0.21 & 2.29 & monoterpene \\
\hline 79 & $\alpha$-terpineol & 2.98 & 0.20 & 0.69 & 11.11 & monoterpene \\
\hline 80 & $\alpha$-terpinyl acetate & 42.65 & 0.46 & 0.21 & 0.31 & monoterpene \\
\hline 81 & ar-turmerone & - & 12.28 & - & - & sesquiterpene \\
\hline 82 & $\beta$-turmerone & - & 25.77 & - & - & sesquiterpene \\
\hline 83 & Tricyclene & - & - & 0.12 & 0.11 & monoterpene \\
\hline 84 & Thymol & - & 0.48 & - & - & monoterpene \\
\hline 85 & 2-undecanone & - & - & 0.38 & - & other \\
\hline 86 & Valencene & - & - & - & 0.35 & sesquiterpene \\
\hline 87 & $\alpha$-zingiberene & - & 5.13 & 22.69 & - & sesquiterpene \\
\hline \multicolumn{2}{|c|}{ Total monoterpenes (\%) } & 93.04 & 9.26 & 25.52 & 77.40 & \\
\hline \multicolumn{2}{|c|}{ Total sesquiterpenes (\%) } & 0.11 & 78.29 & 58.42 & 9.22 & \\
\hline \multicolumn{2}{|c|}{ Other compounds (\%) } & - & 2.48 & 0.58 & 3.07 & \\
\hline \multicolumn{2}{|c|}{ Total compounds identified (\%) } & 93.15 & 90.03 & 84.52 & 89.69 & \\
\hline
\end{tabular}

From these results (Table 1), it can be concluded that monoterpenes generally predominate in cardamom and galangal EOs, while sesquiterpenes are mainly found in turmeric and ginger EOs. Interestingly, cardamom rhizome contains the highest content of $\alpha$-terpinyl acetate, which occurs in the low concentrations in the other herbs. The variations in the content of common individual compounds found in EOs of the Zingiberaceae species studied are shown in Figure 1.

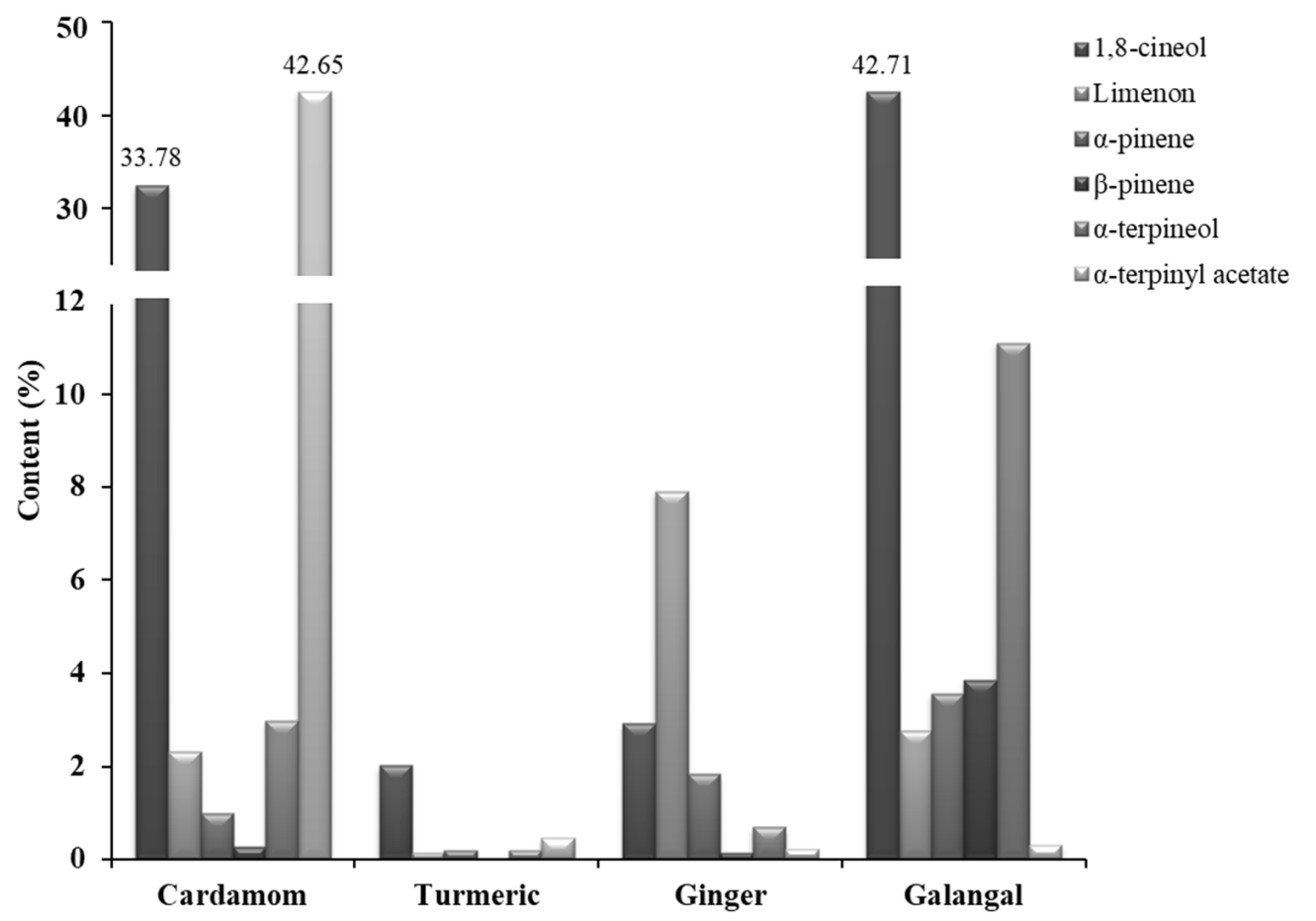

Figure 1. Comparison of the content of the most common chemical constituents found in the EOs of four selected Zingiberaceae species. 
The highest extraction yield of EO in this study was achieved with cardamom fruits originating from Guatemala (3.74\%). Compared to the previously published works, this result was slightly higher. For example, Singh et al. achieved an extraction yield of 3.1\% for the Indian samples [42], while Kuyumcu Savan and Küçükbay reported an extraction yield of $1 \%$ for the 3 -h hydrodistillation of dried cardamom fruits from Turkey [43]. In our particular case, based on the GC-MS/MS analysis, a total of 22 chemical constituents were identified tentatively (Figure S1), which represents $99.15 \%$ of the total peak value recorded (Table 1). The most important compounds (99.04\%) were monoterpenes, among which $\alpha$-terpinyl acetate (42.65\%) and 1,8-cineol/eucalyptol (33.78\%) dominated. In addition to many proven pharmaceutical properties of cardamom EO (antioxidant, anti-inflammatory, antibacterial, anticancer, antifungal, and insecticidal effects) $[3,14]$, the recently published study also showed that $\alpha$-terpinyl acetate has multi-target directed ligand (MTDL) potential in Alzheimer's disease [44]. The other compounds with a significant content in cardamom EO were $\alpha$-terpineol (2.98\%), linalool (2.72\%), limonene (2.32\%), 4-terpineol $(1.85 \%)$, and sabinene $(1.82 \%)$. These results are in good agreement with the previously published works for the cardamom samples from Guatemala [32,45,46].

The extraction yield for EO from curcuma rhizome was $0.25 \%$, which is comparable with the results published by Naz et al., who achieved a yield of $0.67 \%$ for the Pakistani sample [47], but significantly lower than the result published by Zhang et al. (4.03\%) for the samples from China [48]. This inconsistency in the results can be explained by differences in the origin of the sample, the time of harvest, the characteristics of the sample (dried or fresh samples), and the extraction method used [49]. Similarly, the plant material analyzed in this work represents the products available on the Slovenian market. Consequently, the process of storage, distribution, and preservation may influence the chemical composition and quality of the products themselves [50-52]. The most important of the 44 compounds identified in our specific sample were $\beta$-turmerone $(25.77 \%)$ and ar-turmerone $(12.28 \%)$, followed by ar-curcumen $(11.42 \%), \beta$-sesquiphellandrene (10.44\%), curlone $(7.59 \%)$, and $\alpha$-zingiberene $(5.13 \%)$ (Table 1 and Figure S2). The results are in good agreement with those presented in the previously published studies on the characterization of curcuma samples from China $[2,16]$. However, in the curcuma samples from India, the mainly confirmed volatile integrities were $\alpha$-phellandrene, $\beta$-sesquiphellandrene, and 1,8-cineol [17]. Furthermore, the chemical composition of the curcuma leaves differs significantly from the chemical composition of the rhizome. In fact, EO of the curcuma leaves contains terpinol (52.88\%) and $\alpha$-phellandrene $(21.13 \%)$ as the main constituents [53]. However, clinical studies have shown that turmerones (in particular ar-turmerone and $\beta$-turmerone) are the dominant compounds responsible for the pharmaceutical properties of curcuma EO, justifying greater use of the turmeric rhizome over the plant leaves [54]. Indeed, based on the studies published so far, anti-inflammatory [55], anti-invasion [55], anti-angiogenic [54], and anti-tumor [20] effects of turmerones have been reported.

In the case of the ginger rhizome originating from Madagascar, the yield of the extracted EO was $0.29 \%$, and was comparable to the previously published results for the hydrodistillation. For example, Al-Dhahli et al. reported extraction yields of $0.14 \%$ and $0.20 \%$ for Chinese and Saudi ginger [36]. However, a significantly improved extraction yield (2.62\%) was achieved by Mesomo et al., who used supercritical $\mathrm{CO}_{2}$ at $25.0 \mathrm{MPa}$ and $333.15 \mathrm{~K}$ without reporting changes in oil quality [31]. The main components identified in our sample were $\alpha$-zingiberene $(22.69 \%)$, ar-curcumene $(11.63 \%), \beta$-sesquiphellandren $(10.08 \%)$, limonene $(7.90 \%)$ and $\beta$-bisabolene $(7.55 \%)$ (Figure 53$)$. The results are in good agreement with the recently published study by Camero et al. [56]. Several other studies have also confirmed $\alpha$-zingiberene as the main ingredient of ginger EO from Ghana, Thailand, Poland, Nigeria, Australia and India [36,57,58], while ar-curcumene has been identified as the main ingredient of Brazilian and Cuban genotypes [59]. From a pharmaceutical point of view, ginger extracts represent a potentially effective preventive agent against various carcinogenic cells [60]. 
Finally, the yield of EO extracted from the galangal rhizome was $0.35 \%$, with no difference between the results published by Raina et al. [29]. Fifty-three compounds representing $89.69 \%$ of the total oil were tentatively identified by GC-MS/MS and are listed in Table 1. The main compounds identified were 1,8-cineol $(42.71 \%), \alpha$-terpineol $(11.11 \%)$, followed by camphene $(4.58 \%), \beta$-pinene $(3.85 \%), \alpha$-pinene $(3.56 \%)$, limonene $(2.76 \%), 4$-terpineol $(2.29 \%)$, and camphor $(2.24 \%)$ (Figure S4). The occurrence of 1,8cineol as the main component of the rhizome oil of A. galanga in the present study is consistent with earlier published results [2,28,29]. 1,8-cineol, also known as eucalyptol, has demonstrated several clinical activities including therapeutic benefits in inflammatory airway diseases, such as asthma or chronic obstructive pulmonary disease [61], and it also possesses anti-inflammatory [62] and anti-oxidative [62] properties.

\subsection{Total Phenolic Content (TPC) of the Crude Extracts}

Figure 2 shows the total phenolic content (TPC), expressed as mg gallic acid equivalent per gram of dry weight (mg GA g $\left.{ }^{-1} \mathrm{DW}\right)$ for aq. $\mathrm{MeOH}(80 \% \mathrm{MeOH})$, aq. $\mathrm{EtOH}(80 \%$ $\mathrm{EtOH}$ ) and water extracts of the selected Zingiberaceae species. In general, TPC values varied significantly between the plant samples, ranging from $1.13 \mathrm{mg} \mathrm{GA} \mathrm{g}^{-1} \mathrm{DW}$ to $63.00 \mathrm{mg} \mathrm{GA} \mathrm{g}^{-1} \mathrm{DW}$. On the other hand, no statistically significant difference was generally found between the extraction efficiency of $80 \% \mathrm{MeOH}$ and $80 \% \mathrm{EtOH}$ for TPC. However, the extraction efficiency of ultrapure water was the lowest in all tests, except for the cardamom rhizome, where the same-very low TPC values were achieved in all evaluated solvents. The choice of the appropriate solvent from the point of view of the utilization of the extraction, but also its impact on the environment, is one of the most important factors in the selection of an extraction technique. Although some authors have highlighted methanol as the best solvent for the extraction of bioactive plant constituents [63,64], the use of so-called GRAS (generally recognized as safe) solvents such as water or aqueous ethanol solutions is a desirable alternative for the further use of the extracts obtained in the cosmetic, food and pharmaceutical industries $[65,66]$. Consequently, from the results presented in Figure 2, we can generally conclude that $80 \% \mathrm{EtOH}$ represents a good extraction solvent for isolation of bioactive components from plant material of Zingiberaceae species.

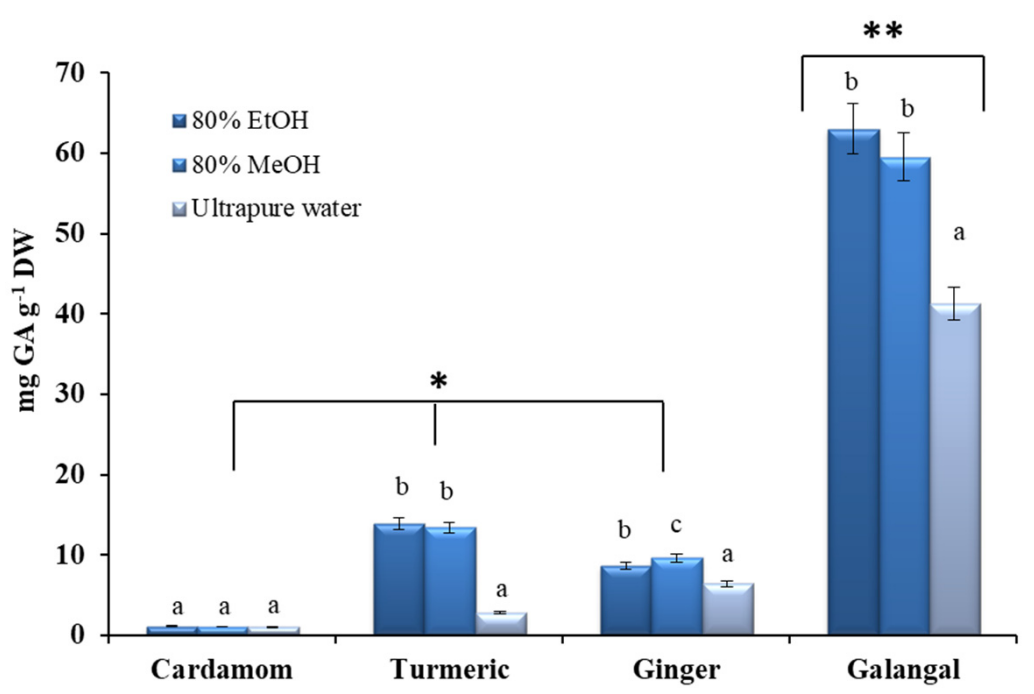

Figure 2. Total phenolic content (TPC) for crude extracts of the selected Zingiberaceae species, expressed as mg of gallic acid equivalents per gram of dry weight ( $\left.\mathrm{mg} \mathrm{GA} \mathrm{g}^{-1} \mathrm{DW}\right)$. All measurements were performed in duplicate. For comparison of the mean values, one-way ANOVA followed by $\mathrm{S}-\mathrm{N}-\mathrm{K}$ post hoc was used. Different superscript letters indicate statistical differences in the extraction efficiency of the tested solvents $(p<0.05)$, while asterisks indicate statistical differences in TPC content between different plants $(p<0.05)$. 
Comparing the content of bioactive phenolic compounds expressed as TPC among the studied plants, the lowest TPC value was determined in cardamom rhizome and correlates well with previously published studies $[24,33,38]$. The low TPC content in cardamom can be explained by the fact that the flavonoid diosmin, the most important single phenolic compound [38], is practically insoluble in water and poorly soluble in polar organic solvents (e.g., $\mathrm{EtOH}, \mathrm{MeOH})[67]$.

In the case of the turmeric rhizome, the TPC of the water extract was $2.80 \pm 0.19 \mathrm{mg}$ $\mathrm{GA} \mathrm{g}^{-1} \mathrm{DW}$, while the TPC values measured in the alcoholic extracts were significantly higher, namely $13.40 \pm 0.66 \mathrm{mg} \mathrm{GA} \mathrm{g}^{-1} \mathrm{DW}$ and $13.93 \pm 0.81 \mathrm{mg} \mathrm{GA} \mathrm{g}^{-1} \mathrm{DW}$ for $80 \%$ $\mathrm{MeOH}$ and $80 \% \mathrm{EtOH}$, respectively. Again, the results can be explained by the practical insolubility in water $\left(<8 \mu \mathrm{g} \mathrm{mL}^{-1}\right)$ of the main bioactive turmeric compounds (curcuminoids), and their good solubility in polar organic solvents, like methanol and ethanol [68]. However, our results for curcuma were somewhat higher compared to the recently published work of Yang et al. [69]. The disagreement in the results can be explained by differences in the origin of the samples, as we analyzed curcuma sample from India, while Yang et al. analyzed a Chinese sample [69].

In the case of the ginger rhizome, the highest TPC value $\left(9.63 \pm 0.05 \mathrm{mg} \mathrm{GA} \mathrm{g}^{-1}\right.$ DW) was found in the methanolic extract, while water resulted in the lowest TPC content $\left(6.42 \pm 0.33 \mathrm{mg} \mathrm{GA} \mathrm{g}^{-1} \mathrm{DW}\right)$. Similar results were observed in the study by Hester et al. [70].

Finally, the galangal extracts showed the highest TPC values without a statistically significant difference in the content between the $80 \% \mathrm{EtOH}\left(63.00 \pm 1.06 \mathrm{mg} \mathrm{GA} \mathrm{g}^{-1} \mathrm{DW}\right)$ and $80 \% \mathrm{MeOH}\left(59.52 \pm 4.75 \mathrm{mg} \mathrm{GA} \mathrm{g}^{-1} \mathrm{DW}\right)$. As previously reported, in addition to the volatile compounds identified in EO, the galangal rhizome is a rich source of various flavonoids, including kaempferol, apigenin, luteolin, quercetin, and isorhamnetin [37]. Our results for TPC (for the samples originating from China) are comparable to the results reported by Lu et al. [39].

\subsection{Antioxidant Properties of Crude Extracts and Essential Oils of Zingiberaceae Species}

In this study, two different in vitro tests, ferric reducing antioxidant capacity (FRAP) and ABTS radical scavenging activity, were also performed to evaluate the antioxidant properties of crude extracts and essential oils of selected plant material.

\subsubsection{FRAP Assay}

FRAP assay of the crude extracts and essential oils was evaluated and the final results were expressed as $\mathrm{mg} \mathrm{Fe} \mathrm{Fe}^{2+}$ per gram of dry weight ( $\mathrm{mg} \mathrm{Fe}^{2+} \mathrm{g}^{-1} \mathrm{DW}$ ) and $\mathrm{mg} \mathrm{Fe} \mathrm{Fe}^{2+}$ per milliliter of essential oils ( $\mathrm{mg} \mathrm{Fe}^{2+} \mathrm{mL}^{-1} \mathrm{EO}$ ), respectively.

In the case of crude extracts (Figure 3), alcoholic extracts have the highest antioxidant capacity, although for cardamom and galangal no statistically significant difference was found between the solvents tested. These results are in good agreement with the results published by Lu et al., who evaluated the antioxidant capacity of the 15 commonly used species from China [39].

As shown in Figure 3, the highest values (between $75.39 \pm 10.57 \mathrm{mg} \mathrm{Fe}^{2+} \mathrm{g}^{-1} \mathrm{DW}$ and $92.02 \pm 4.09 \mathrm{mg} \mathrm{Fe}^{2+} \mathrm{g}^{-1} \mathrm{DW}$ ) were found for galangal. A similar trend was observed in the study by Köse et al., who evaluated the antioxidant activity of galangal extracts obtained with water, ethanol and water/ethanol mixture [37]. On the other hand, the lowest FRAP values were observed for cardamom fruits. Finally, no statistically significant difference was found between the reduction capacity of turmeric and ginger crude extracts (Figure 3). The highest FRAP value for turmeric was observed for ethanolic extract $\left(20.82 \pm 0.42 \mathrm{mg} \mathrm{Fe}^{2+} \mathrm{g}^{-1} \mathrm{DW}\right)$, which was comparable to the results published by Yang et al. [69]. In the case of the ginger rhizome, the same values were determined for ethanolic (20.73 $\left.\pm 0.70 \mathrm{mg} \mathrm{Fe}^{2+} \mathrm{g}^{-1} \mathrm{DW}\right)$ and methanolic (20.82 $\pm 0.42 \mathrm{mg} \mathrm{Fe}^{2+} \mathrm{g}^{-1}$ DW) extracts, while water was inferior as the extraction solvent with a FRAP value of $11.58 \pm 1.26 \mathrm{mg} \mathrm{Fe}^{2+} \mathrm{g}^{-1} \mathrm{DW}$. 


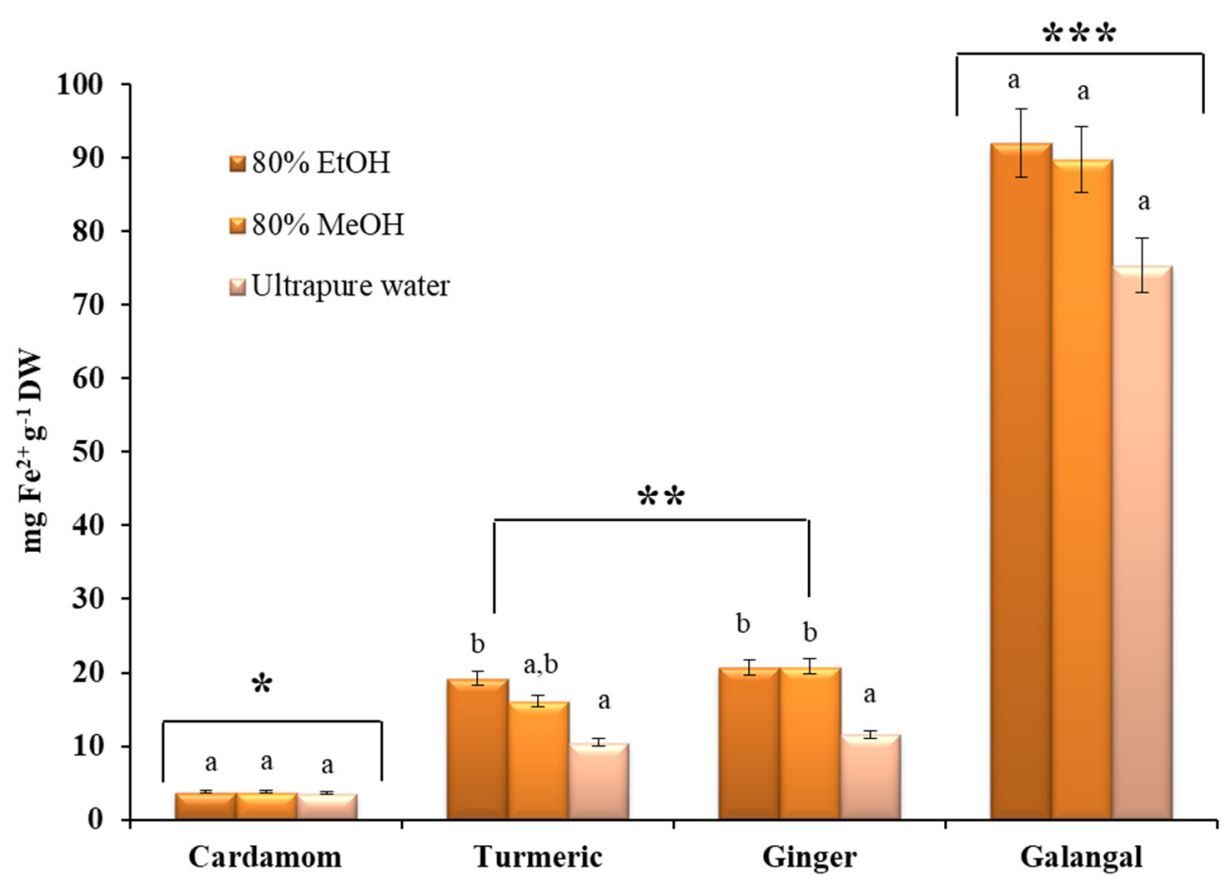

Figure 3. Antioxidant activity of selected Zingiberaceae species expressed as $\mathrm{mg} \mathrm{Fe}^{2+}$ ion equivalents per gram of dry weight $\left(\mathrm{mg} \mathrm{Fe}^{2+} \mathrm{g}^{-1} \mathrm{DW}\right)$. All measurements were performed in duplicate. For comparison of the mean values, one-way ANOVA followed by S-N-K post hoc were applied. A different superscript letters $(a, b)$ indicate a statistical difference in the extraction efficiencies of the solvents tested $(p<0.05)$, while asterisks indicate statistical differences in antioxidant activity between different plants $(p<0.05)$.

The reducing power of the EOs (Figure 4) was again the lowest for the cardamom sample, while the highest FRAP value was obtained for the EO from turmeric. In contrast to the crude extracts, the EO from galangal showed weaker ferric reducing power. Ginger and galangal oils showed similar antioxidant activities as the study published by Avci et al. [71]. These results can probably be explained by differences in the chemical composition within the EOs studied. Namely, ginger EO and especially turmeric EO are rich in sesquiterpenes, whereas the dominant volatile compounds in cardamom and galangal were monoterpenes. Turmerones (especially ar-turmerone and $\beta$-turmerone) are the main compounds believed to be responsible for the antioxidant properties of turmeric EO [72]. For example, in the study of Gounder and Lingamallu, which demonstrated high antioxidant activity of turmeric EO, a significant correlation was found between the reduction of FRAP and the decrease of turmerone content [49]. A similar trend was also observed in the study published by Avanço et al. [16].

\subsubsection{ABTS Assay}

In addition, ABTS assay was performed, where the ability of the crude extracts and EOs to scavenging the $\mathrm{ABTS}^{\bullet+}$ was expressed as mg trolox equivalent per gram of dry weight ( $\left.\mathrm{mg} \mathrm{TE} \mathrm{g}^{-1} \mathrm{DW}\right)$ or $\mathrm{mg}$ trolox equivalent per milliliter of essential oil (mg TE mL $\mathrm{EO})$, respectively.

In the case of the crude extracts, it can generally be concluded that galangal possesses the highest $\mathrm{ABTS}^{\bullet+}$ scavenging activity, while no significant differences were found between the other three plants (Figure 5). By comparison, Köse at al. showed that galangal has marked antioxidant, anticholinergic, reducing, radical scavenging, and metal binding activity [37]. 


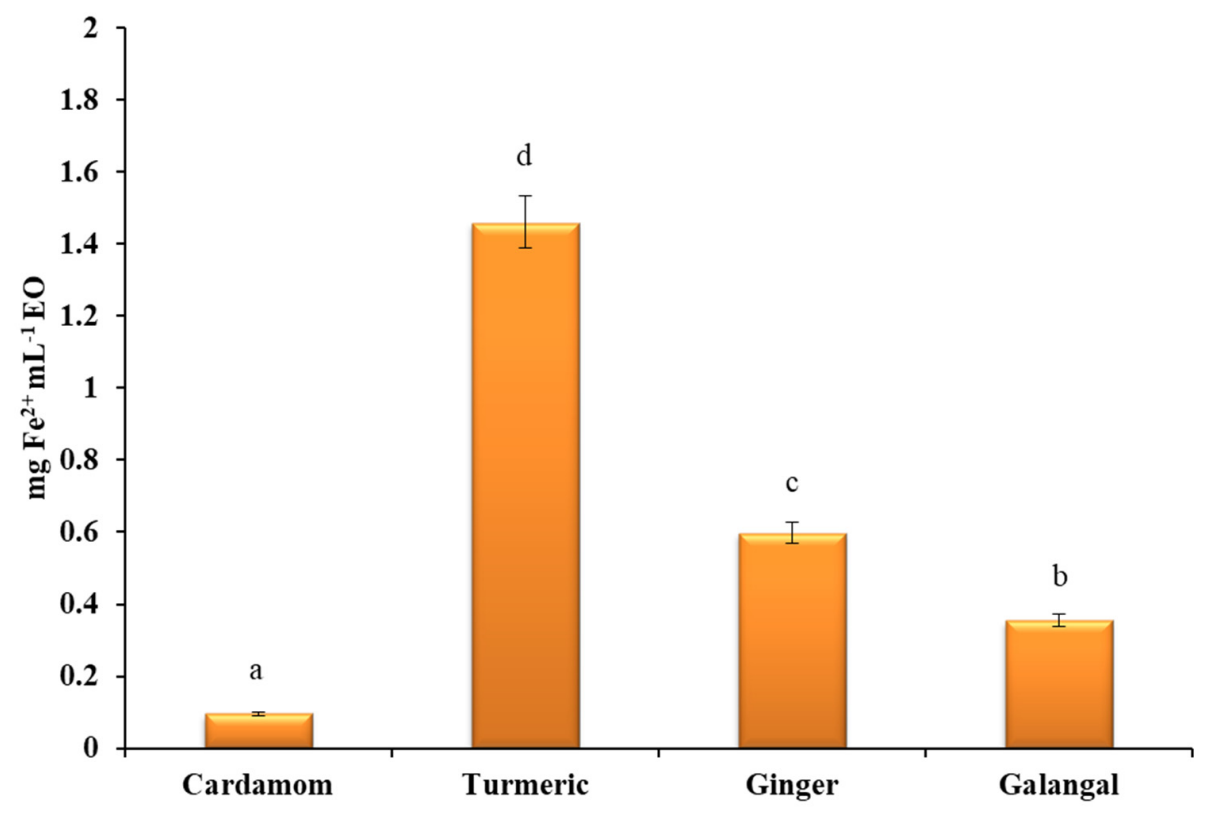

Figure 4. Antioxidant activity of EOs expressed as $\mathrm{mg} \mathrm{Fe}^{2+}$ ion equivalents per milliliter of essential oil ( $\mathrm{mg} \mathrm{Fe}^{2+} \mathrm{mL}^{-1} \mathrm{EO}$ ). All measurements were performed in duplicate. For comparison of the mean values, one-way ANOVA followed by S-N-K post hoc were applied. A different superscript letters $(\mathrm{a}, \mathrm{b}, \mathrm{c}, \mathrm{d})$ indicate a statistical difference in AA of evaluated EOs $(p<0.05)$.

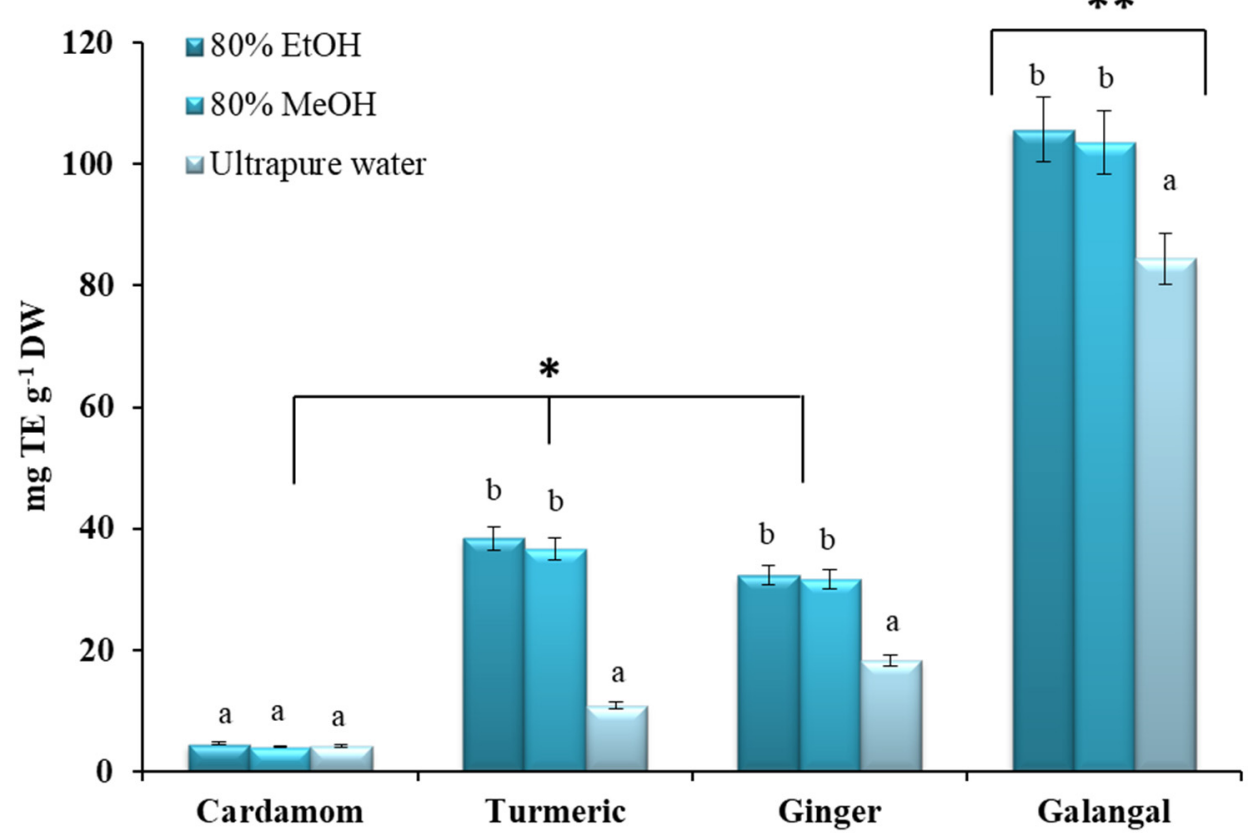

Figure 5. Antioxidant activity of selected Zingiberaceae species expressed as mg trolox equivalents per gram of dry weight (mg TE $\left.\mathrm{g}^{-1} \mathrm{DW}\right)$. All measurements were performed in duplicate. For comparison of the mean values, one-way ANOVA followed by S-N-K post hoc were applied. A different superscript letters $(a, b)$ indicate a statistical difference in the extraction efficiencies of the solvents tested $(p<0.05)$, while asterisks indicate statistical differences in antioxidant activity between different plants $(p<0.05)$.

In the case of cardamom rhizome, similar, very low results (ranging from $4.10 \mathrm{mg} \mathrm{TE}$ $\mathrm{g}^{-1} \mathrm{DW}$ to $4.57 \mathrm{mg} \mathrm{TE}^{-1} \mathrm{DW}$ ) were observed for all solvents tested (Figure 5). These results are in good agreement with results reported by Przygodzka et al. who classified 
cardamom in the group of species with low antioxidant activity [33]. Przygodzka et al. have also confirmed a statistically significant correlation between the TPC of the crude ethanolic extracts and the antioxidant ability of the studied plant material [33].

In contrast, no differences were found between $80 \% \mathrm{EtOH}$ and $80 \% \mathrm{MeOH}$ for turmeric, ginger and galangal, while water extracts showed the lowest values. Compared to the results published by Yang et al., for ABTS values for $80 \% \mathrm{EtOH}$ turmeric extract, the results obtained in our study were slightly higher [69]. However, the study by Yang et al., confirmed a positive statistically significant difference in the extraction efficiency of UAE over the conventionally used solid/liquid extraction [69]. In general, our results are in good agreement with the results of Sana et al. [73], who investigated the effect of extraction parameters and extraction solvents on the antioxidant activity of turmeric.

Finally, in this study, the TPC values of the crude extracts of Zingiberaceae species obtained with the tested solvents $(80 \% \mathrm{EtOH}, 80 \% \mathrm{MeOH}$ and water) were highly positively correlated with the AA values determined by ABTS and FRAP assays. The highest positive correlation (0.01 significant level) was observed for the water extracts with the correlation coefficients of $r=0.999$ and 0.998 between TPC and ABTS and between TPC and FRAP, respectively. In the case of alcoholic extract, TPC was positively correlated with ABTS at the significant level of 0.05 ( $r=0.985$ and $r=0.988$ for $80 \%$ EtOH and $80 \% \mathrm{MeOH}$, respectively), while the higher correlation (0.01 significant level) was found between TPC and FRAP values ( $r=0.995$ for ethanolic extracts and $r=0.994$ for methanolic extracts).

A statistically significant difference was found in the EOs among all the species studied (Figure 6). Compared to the crude extracts, the EOs generally showed weaker $\mathrm{ABTS}^{\bullet+}$ scavenging activity. The highest ABTS value expressed as trolox equivalents (4.14 mg TE mL $\mathrm{mL}^{-1} \mathrm{EO}$ ) was observed for turmeric EO, followed by galangal, ginger, and finally cardamom EO.

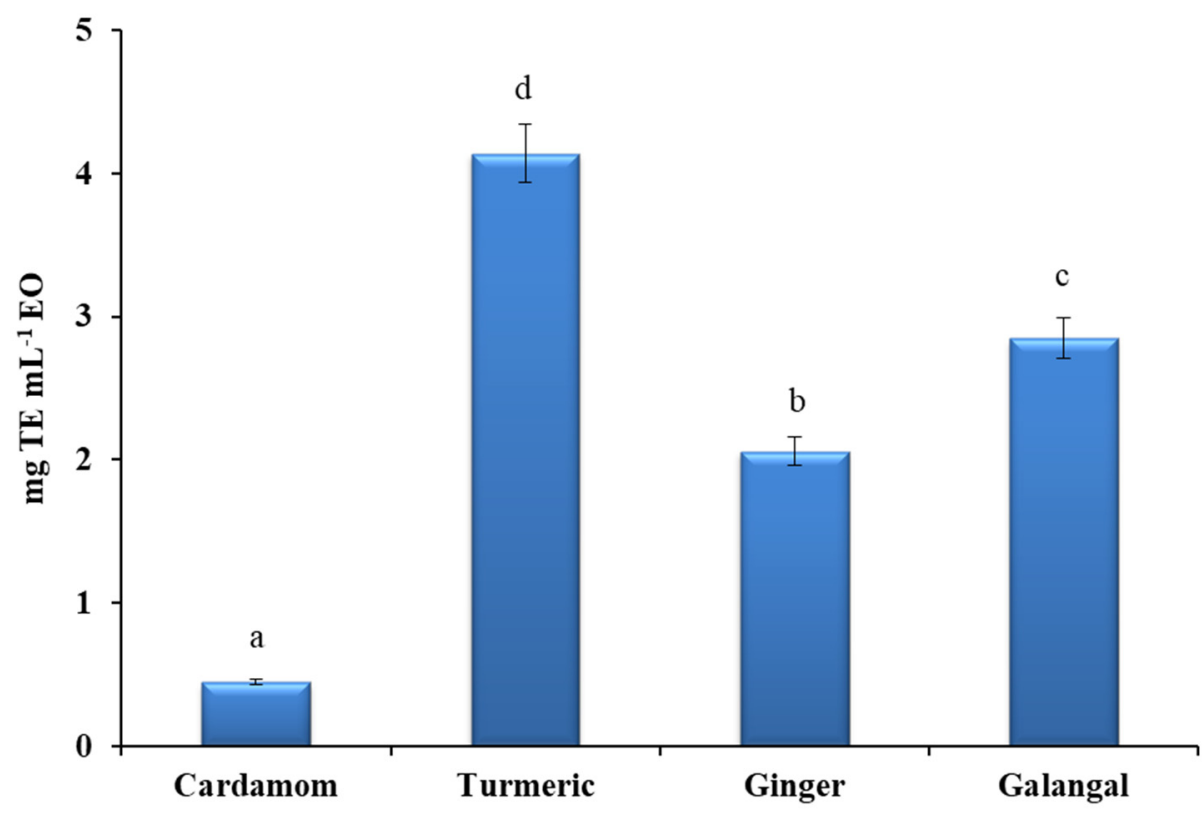

Figure 6. Antioxidant activity of EOs expressed as $\mathrm{mg}$ trolox equivalents per milliliter of essential oil (mg TE mL $\left.{ }^{-1} \mathrm{EO}\right)$. All measurements were performed in duplicate. For comparison of the mean values, one-way ANOVA followed by S-N-K post hoc were applied. Different superscript letters $(a, b$, $c, d)$ indicate a statistical difference in AA of evaluated EOs $(p<0.05)$.

\section{Materials and Methods}

\subsection{Chemicals and Plant Material}

Folin Ciocalteu's reagent (FCR), anhydrous $\mathrm{Na}_{2} \mathrm{CO}_{3}, \mathrm{FeSO}_{4} \cdot 7 \mathrm{H}_{2} \mathrm{O}$, acetic acid (99.8\%) and gallic acid standard (99\%) were supplied by Merck (Darmstadt, Germany). 2,4,6-tris(2pyridyl)-s-triazine (TPTZ reagent, $\geq 99 \%$ ), 2,2'-azino-bis (3-ethylbenzothiazoline-6-sulfonic 
acid) diammonium salt (ABTS reagent), ( \pm )-6-hydroxy-2,5,7,8-tetramethylchromane-2carboxylic acid (trolox, $97 \%$ ), potassium persulfate $\left(\mathrm{K}_{2} \mathrm{~S}_{2} \mathrm{O}_{8}\right), \mathrm{FeCl}_{3} \cdot 6 \mathrm{H}_{2} \mathrm{O}$, sodium acetate $\left(\mathrm{CH}_{3} \mathrm{COONa}\right)$, anhydrous sodium sulfate $\left(\mathrm{Na}_{2} \mathrm{SO}_{4}\right)$ and $n$-hexane $(97 \%)$ were from Sigma Aldrich (St. Louis, MO, USA). HPLC-grade methanol (MeOH) and ethanol (EtOH, 96\%) were supplied by Honeywell (Frankfurter, Germany), while ultrapure water was treated in the laboratory on a daily basis.

Dried plant material of selected Zingiberaceae species (cardamom, turmeric, ginger and galangal) was generously provided by the specialized market "Natural loti" Rakek, Slovenia. In accordance with the supplier specification, the plant material was dried in drying chambers at a controlled temperature $\left(30^{\circ} \mathrm{C}\right)$, with constant air circulation and while maintaining optimum humidity conditions. Prior to distribution, the dried material was stored in dry, airy, and cool areas, packed in tightly sealed containers to preserve flavor, color, and aroma and prevent access to moisture. The laboratory samples were ground in the electric blender (Profi Cook PC-KSW1021) for $1 \mathrm{~min}$ at room temperature, homogenized, and kept in a dark location before analysis. Information on the analyzed plant material is presented in Table 2.

Table 2. Information of the analyzed plant material.

\begin{tabular}{cccc}
\hline Common Name & Latin Name & Plant Part & Origin \\
\hline Cardamom & Elettaria cardamomum L. Maton & fruits & Guatemala \\
Turmeric & Curcuma longa L. & rhizome & India \\
Ginger & Zingiber officinale Roscoe & rhizome & Madagascar \\
Galangal & Alpinia officinarum Hance & rhizome & China \\
\hline
\end{tabular}

\subsection{Hydrodistillation of eEssential Oils from the Selected Species of Zingiberaceae Family}

For the extraction of the essential oils (EOs) the classical hydrodistillation in the Clevenger apparatus was carried out [35]. Here, $100 \mathrm{~g}$ of the ground plant material was weighed and $600 \mathrm{~mL}$ ultrapure water was added. The heating temperature of the calotte was set to $130^{\circ} \mathrm{C}$, and the extraction was performed under these conditions for $3 \mathrm{~h}$. The oils collected over anhydrous sodium sulfate were automatically weighed and analyzed. All extractions were carried out in duplicate.

\subsection{GC and GC-MS/MS Analysis of the Essential Oils}

For chemical identification and quantification, $1 \mu \mathrm{L}$ of properly diluted EOs in $n$ hexane $(1: 20, v: v)$ was analyzed using a gas chromatograph Varian Saturn $2100 \mathrm{~T}$ coupled to a MS/MS Saturn 2100 ion trap mass spectrometer. The chromatographic separation was performed with the capillary column VF- $5 \mathrm{~ms}(30 \mathrm{~m} \times 0.25 \mathrm{~mm} \times 0.25 \mu \mathrm{m})$. The split injection mode was used (split ratio 1:20), while He 6.0 was used as carrier gas with a flow rate of $1 \mathrm{~mL} \mathrm{~min}{ }^{-1}$. The injector temperature was set to $230{ }^{\circ} \mathrm{C}$. The initial oven temperature was set to $40^{\circ} \mathrm{C}$ for $4 \mathrm{~min}$, then the temperature was raised to $150{ }^{\circ} \mathrm{C}$ at a rate of $5{ }^{\circ} \mathrm{C}$ per min and held at this temperature for $13 \mathrm{~min}$. In addition, the column was heated up to $200{ }^{\circ} \mathrm{C}$ at a rate of $10{ }^{\circ} \mathrm{C}$ and finally kept at $200{ }^{\circ} \mathrm{C}$ for the next $15 \mathrm{~min}$. The total running time was $59 \mathrm{~min}$. The mass spectra were recorded in the SCAN mode in a range from 50 to $650 \mathrm{~m} / z$ using electron ionization energy at $70 \mathrm{eV}$ and the detector temperature was set to $150{ }^{\circ} \mathrm{C}$. The volatile compounds were identified by comparing the mass spectra of the compounds in plant samples with those available in the NIST library and the data available in the literature.

\subsection{Preparation of Crude Solvent Extracts by Ultrasound-Assisted Extraction (UAE)}

For the evaluation of the content of non-volatile bioactive compounds, an UAE extraction was carried out. For this purpose, $500 \mathrm{mg}$ of ground plant material was weighed into a $50 \mathrm{~mL}$ conical centrifuge tube and $10 \mathrm{~mL}$ of selected solvent $(80 \% \mathrm{MeOH}$ or $80 \% \mathrm{EtOH}$ or ultrapure $\mathrm{H}_{2} \mathrm{O}$ ) was added. The extractions were performed in an ultrasonic bath (Vevor, Shanghai, China) under the evaluated temperature $\left(50 \pm 1^{\circ} \mathrm{C}\right)$ for $30 \mathrm{~min}$. The extracts 
obtained were then centrifuged with a laboratory centrifuge (Eppendorf, 5804R, Hamburg, Germany) for $10 \mathrm{~min}$ at $10,000 \mathrm{rpm}$ and the same extraction protocol was repeated once again with new $10 \mathrm{~mL}$ of the extraction solvent $(80 \% \mathrm{MeOH}$ or $80 \% \mathrm{EtOH}$ or ultrapure $\mathrm{H}_{2} \mathrm{O}$ ). The supernatants were combined in a $25 \mathrm{~mL}$ volumetric flask and made up to the mark with a suitable solvent. Before analysis, the extracts were filtered through a $0.45 \mu \mathrm{m}$ PTFE filter and properly diluted (usually 1:5, v:v). All extractions and instrumental analysis were performed in duplicate.

\subsection{Determination of Total Phenolic Content (TPC) of Crude Solvent Extracts}

The total phenolic content (TPC) for the crude extracts of the selected Zingiberaceae species was determined by the standard spectrophotometric method first described by Singleton, with some modifications [74,75]. First, different concentrations $(25,50,100,150$, 250, and $500 \mathrm{mg} / \mathrm{L}$ ) of the standard solutions of gallic acid were prepared. After that, $3160 \mu \mathrm{L}$ of ultrapure water was mixed with $40 \mu \mathrm{L}$ of properly diluted extracts or gallic acid standard solutions and $200 \mu \mathrm{L}$ of a $10 \%$ FC reagent. The mixture was left to stand for 6 min and $600 \mu \mathrm{L}$ of a $20 \% \mathrm{Na}_{2} \mathrm{CO}_{3}$ solution (w:v) was added. After $2 \mathrm{~h}$ of incubation at the dark place, the absorbances were measured at $765 \mathrm{~nm}$ against ultrapure water as a blank. The concentrations were expressed as mg gallic acid equivalent per gram of dry weight (mg GA g $\left.{ }^{-1} \mathrm{DW}\right)$.

\subsection{Determination of Antioxidant Activity of Crude Extracts and Essential Oils 3.6.1. ABTS Radical Scavenging Assay}

The cationic $\mathrm{ABTS}^{\bullet+}$ radical solution was prepared by mixing equal volumes of a $7 \mathrm{mM}$ solution of ABTS (2,2'-azino-bis(3-ethylbenzothiazoline-6-sulfonic acid) diammonium salt) and a $2.4 \mathrm{mM}$ solution of potassium persulfate $\left(\mathrm{K}_{2} \mathrm{~S}_{2} \mathrm{O}_{8}\right)$ and was incubated for $12-16 \mathrm{~h}$ in a dark place at room temperature (RT). Before use, this solution was further diluted with absolute $\mathrm{EtOH}$ to adjust the absorbance to $0.70 \pm 0.05$ at $734 \mathrm{~nm}$ (about $1 \mathrm{~mL}$ of ABTS ${ }^{\bullet+}$ solution corresponds to $55-60 \mathrm{~mL}$ of $\mathrm{EtOH}$ ) [76]. In addition, $3950 \mu \mathrm{L}$ of the reaction solution was mixed with $50 \mu \mathrm{L}$ of standard trolox solutions (in the concentration range of 0.1-1.0 $\mathrm{mM}$ ) or properly diluted crude extracts or properly diluted essential oils. After a 30 min incubation in the dark at RT, the absorbances at $734 \mathrm{~nm}$ were measured against the blank solution ( $3950 \mu \mathrm{L} \mathrm{ABTS}{ }^{\bullet+}$ and $50 \mu \mathrm{L}$ absolute EtOH). The scavenging effect, expressed in \%, was calculated using the following equation:

$$
\text { Scavenging effect }(\%)=\frac{(\mathrm{AB}-\mathrm{AA})}{\mathrm{AB}} \times 100
$$

where $\mathrm{AB}$ represents the absorbance of the mixture of $\mathrm{ABTS}^{\bullet+}$ and EtOH (blank value), while AA represents the absorbance of the mixture of $\mathrm{ABTS}^{\bullet+}$ and trolox solution/extract/EO. The final concentrations were expressed as $\mathrm{mg}$ trolox equivalent per gram of dry weight (mg TE $\mathrm{g}^{-1} \mathrm{DW}$ ) or $\mathrm{mg}$ trolox equivalent per milliliter of essential oil ( $\mathrm{mg} \mathrm{TE} \mathrm{mL}^{-1} \mathrm{EO}$ ), respectively.

\subsubsection{Ferric Reducing Antioxidant Power Test (FRAP Assay)}

The antioxidant activity of the crude extracts, expressed as $\mathrm{mg} \mathrm{Fe}^{2+}$ ion equivalent per gram of dry weight $\left(\mathrm{mg} \mathrm{Fe}^{2+} \mathrm{g}^{-1} \mathrm{DW}\right)$ and essential oils, expressed as $\mathrm{mg} \mathrm{Fe}^{2+}$ ion equivalent per milliliter of essential oil $\left(\mathrm{mg} \mathrm{Fe}^{2+} \mathrm{mL}^{-1} \mathrm{EO}\right)$, was determined by a standard spectrophotometric method with slight modifications [77]. In short, the daily fresh reagent FRAP was prepared by mixing acetate buffer $(\mathrm{pH}=3.60), 10 \mathrm{mM}$ TPTZ solution in $40 \mathrm{mM}$ $\mathrm{HCl}$, and $20 \mathrm{mM} \mathrm{FeCl}_{3} 6 \mathrm{H}_{2} \mathrm{O}$ in the volume ratio 10:1:1 at $37^{\circ} \mathrm{C}$ [78]. Working solutions of $\mathrm{Fe}^{2+}$ ions in the concentration range $10-300 \mathrm{mg} \mathrm{L}^{-1}$ were prepared by diluting $20 \mathrm{mM}$ $\mathrm{Fe}^{2+}$ standard solution with ultrapure water. For the measurements, $4950 \mu \mathrm{L}$ of the reagent FRAP was mixed with $50 \mu \mathrm{L}$ of properly diluted crude extracts/properly diluted essential oil or $\mathrm{Fe}^{2+}$ working solutions or properly diluted crude extract or properly diluted essential 
oil. After $30 \mathrm{~min}$ of incubation at $37^{\circ} \mathrm{C}$, the absorbances at $593 \mathrm{~nm}$ were measured against FRAP reagent as a blank value.

\subsection{Statistical Analysis}

All results were expressed as mean value \pm standard deviation. The SPSS software: IBM SPSS Statistics for Windows, Version 22.0 (Armonk, NY: IBM Corp., published 2013) was used for the statistical evaluation of the results obtained. For that purpose, a one-way analysis of variance (ANOVA) at a 95\% confidence level and a Student-Newman-Keuls (S-N-K) post-hoc test were applied. The correlation analysis between TPC and AA of the crude extracts of the selected spices was performed by calculating Pearson's correlation coefficient.

\section{Conclusions}

Many plant species contain valuable EOs that are useful in many different areas, mainly because of their strong odor and because they have been shown to have a wide variety of pharmacological effects. The main constituents of EOs are monoterpenes, which have a pronounced antiseptic and antibacterial effects. In second place are the sesquiterpenes, which have anti-inflammatory and analgesic effects. In our study, we successfully isolated the EOs of four plant species belonging to the Zingiberaceae family, namely cardamom, turmeric, ginger, and galangal, and quantified their major constituents. The results confirmed that 1,8-cineol (2.01-42.71\%), $\alpha$-terpinyl acetate $(0.21-42.65 \%)$, limonene $(0.15-$ $7.90 \%), \alpha$-pinene $(0.20-3.56 \%)$, and $\beta$-pinene $(0.03-3.85 \%)$ were the main monoterpenes in all the oils studied. Antioxidant assay (ABTS and FRAP) pointed out that turmeric EO possessed the highest antioxidant capacity, while the lowest value was determined for cardamom EO. In addition, the antioxidant activity of crude aqueous, ethanolic, and methanolic extracts was compared with different antioxidant assays and the results generally confirmed galangal extracts as those with the strongest antioxidant activity, followed by turmeric and ginger extracts, while cardamom extracts showed the lowest antioxidant capacity. Overall, the best extraction of antioxidant components was obtained when ethanol was used as a solvent followed by extraction with methanol and water. Many papers have been published on the antioxidant activity of Zingiberaceae species. However, the data show much inconsistency between the same essences or extracts, so direct comparison of results is very difficult. The reasons for this variability can be understood by considering all the factors that influence the chemical composition of the obtained extracts, namely climatic, seasonal, and geographical conditions, harvest period, parts of the plant used, distillation or extraction technique and antioxidant activity assay applied, among others. Anyhow, our results confirmed that plant species belonging to the family Zingiberaceae can serve as a good natural source of antioxidant components and natural EOs that can be widely used in modern pharmaceutical, food, nutraceutical, and cosmetic industries.

Supplementary Materials: The following are available online at https:/ /www.mdpi.com/2223-774 7/10/3/501/s1, Figure S1: Typical GC-MS/MS chromatogram of cardamom (Elettaria cardamomum L. Maton) essential oil, Figure S2: Typical GC-MS/MS chromatogram of turmeric (Curcuma longa L.) essential oil, Figure S3: Typical GC-MS/MS chromatogram of ginger (Zingiber officinale Roscoe) essential oil, Figure S4: Typical GC-MS/MS chromatogram of galangal (Alpinia officinarum Hance) essential oil.

Author Contributions: Conceptualization, M.I.R.; methodology, M.I.R. and M.I.; software, M.I.; validation, K.M., M.I. and M.I.R.; formal analysis, M.I. and K.M.; investigation, M.I., K.M., and M.I.R; resources, M.I.R.; data curation, M.I. and K.M.; writing—original draft preparation, M.I. and K.M.; writing—review and editing, M.I.R.; visualization, M.I.; supervision, M.I.R.; funding acquisition, M.I.R. All authors have read and agreed to the published version of the manuscript.

Funding: The authors acknowledged the financial support from the program P2-0006 of the Slovenian Research Agency (ARRS).

Institutional Review Board Statement: Not applicable. 
Informed Consent Statement: Not applicable.

Conflicts of Interest: The authors declare no conflict of interest.

\section{References}

1. Barbosa, G.B.; Jayasinghe, N.S.; Natera, S.H.; Inutan, E.D.; Peteros, N.P.; Roessner, U. From common to rare Zingiberaceae plants-A metabolomics study using GC-MS. Phytochemistry 2017, 140, 141-150. [CrossRef]

2. Zhang, L.; Liang, X.; Ou, Z.; Ye, M.; Shi, Y.; Chen, Y.; Zhao, J.; Zheng, D.; Xiang, H. Screening of chemical composition, antiarthritis, antitumor and antioxidant capacities of essential oils from four Zingiberaceae herbs. Ind. Crop. Prod. 2020, 149, 112342. [CrossRef]

3. Ashokkumar, K.; Murugan, M.; Dhanya, M.; Warkentin, T.D. Botany, traditional uses, phytochemistry and biological activities of cardamom [Elettaria cardamomum (L.) Maton]-A critical review. J. Ethnopharmacol. 2020, 246, 112244. [CrossRef]

4. Ding, P.; Yang, L.; Feng, C.; Xian, J.-C. Research and application of Alpinia officinarum in medicinal field. Chin. Herb. Med. 2019, 11, 132-140. [CrossRef]

5. Zhang, L.; Pan, C.; Ou, Z.; Liang, X.; Shi, Y.; Chi, L.; Zhang, Z.; Zheng, X.; Li, C.; Xiang, H. Chemical profiling and bioactivity of essential oils from Alpinia officinarum Hance from ten localities in China. Ind. Crop. Prod. 2020, 153, 112583. [CrossRef]

6. Jugreet, B.S.; Suroowan, S.; Rengasamy, R.K.; Mahomoodally, M.F. Chemistry, bioactivities, mode of action and industrial applications of essential oils. Trends Food Sci. Technol. 2020, 101, 89-105. [CrossRef]

7. Ma, Y.-N.; Xu, F.-R.; Chen, C.-J.; Li, Q.-Q.; Wang, M.-Z.; Cheng, Y.-X.; Dong, X. The beneficial use of essential oils from buds and fruit of Syzygium aromaticum to combat pathogenic fungi of Panax notoginseng. Ind. Crop. Prod. 2019, 133, 185-192. [CrossRef]

8. Pateiro, M.; Munekata, P.E.; Sant'Ana, A.S.; Domínguez, R.; Rodríguez-Lázaro, D.; Lorenzo, J.M. Application of essential oils as antimicrobial agents against spoilage and pathogenic microorganisms in meat products. Int. J. Food Microbiol. 2021, $337,108966$. [CrossRef]

9. Pinto, L.; Cefola, M.; Bonifacio, M.; Cometa, S.; Bocchino, C.; Pace, B.; De Giglio, E.; Palumbo, M.; Sada, A.; Logrieco, A.; et al. Effect of red thyme oil (Thymus vulgaris L.) vapours on fungal decay, quality parameters and shelf-life of oranges during cold storage. Food Chem. 2021, 336, 127590. [CrossRef]

10. Pinto, L.; Bonifacio, M.A.; De Giglio, E.; Cometa, S.; Logrieco, A.F.; Baruzzi, F. Unravelling the antifungal effect of red thyme oil (Thymus vulgaris L.) compounds in vapor phase. Molecules 2020, 25, 4761. [CrossRef]

11. Baldin, V.P.; Bertin de Lima Scodro, R.; Mariano Fernandez, C.M.; Ieque, A.L.; Caleffi-Ferracioli, K.R.; Dias Siqueira, V.L.; de Almeida, A.L.; Gonçalves, J.E.; Garcia Cortez, D.A.; Cardoso, R.F. Ginger essential oil and fractions against Mycobacterium spp. J. Ethnopharmacol. 2019, 244, 112095. [CrossRef]

12. Anwar, F.; Abbas, A.; Alkharfy, K.M.; Gilani, A.-U.-H. Cardamom (Elettaria cardamomum Maton) Oils; Elsevier: Amsterdam, The Netherlands, 2016; ISBN 9780124166448.

13. Jamil, B.; Abbasi, R.; Abbasi, S.; Imran, M.; Khan, S.U.; Ihsan, A.; Javed, S.; Bokhari, H. Encapsulation of cardamom essential oil in chitosan nano-composites: In-vitro efficacy on antibiotic-resistant bacterial pathogens and cytotoxicity studies. Front. Microbiol. 2016, 7, 1580. [CrossRef]

14. Sengottuvelu, S. Cardamom (Elettaria cardamomum Linn. Maton) seeds in health. In Nuts and Seeds in Health and Disease Prevention; Elsevier: Amsterdam, The Netherlands, 2011; pp. 285-291, ISBN 9780123756886.

15. Cui, H.; Zhang, C.; Li, C.; Lin, L. Inhibition mechanism of cardamom essential oil on methicillin-resistant Staphylococcus aureus biofilm. LWT 2020, 122, 109057. [CrossRef]

16. Avanço, G.B.; Ferreira, F.D.; Bomfim, N.S.; Rodriques dos Santos, P.A.d.S.; Peralta, R.M.; Brugnari, T.; Mallann, A.; Filho, B.A.d.A.; Graton Mikcha, J.M.; Machinski, M., Jr. Curcuma longa L. essential oil composition, antioxidant effect, and effect on Fusarium verticillioides and fumonisin production. Food Control. 2017, 73, 806-813. [CrossRef]

17. Mishra, R.; Gupta, A.K.; Kumar, A.; Lal, R.K.; Saikia, D.; Chanotiya, C.S. Genetic diversity, essential oil composition, and in vitro antioxidant and antimicrobial activity of Curcuma longa L. germplasm collections. J. Appl. Res. Med. Aromat. Plants 2018, 10, 75-84. [CrossRef]

18. Pal, K.; Chowdhury, S.; Dutta, S.K.; Chakraborty, S.; Chakraborty, M.; Pandit, G.K.; Dutta, S.; Paul, P.K.; Choudhury, A.; Majumder, B.; et al. Analysis of rhizome colour content, bioactive compound profiling and ex-situ conservation of turmeric genotypes (Curcuma longa L.) from sub-Himalayan terai region of India. Ind. Crop. Prod. 2020, 150, 112401. [CrossRef]

19. Ahmad, M.; Kamran, S.H.; Mobasher, A. Protective effect of crude Curcuma longa and its methanolic extract in alloxanized rabbits. Pak. J. Pharm. Sci. 2014, 27, 121-128.

20. Kim, Y.; You, Y.; Yoon, H.-G.; Lee, Y.-H.; Kim, K.; Lee, J.; Kim, M.S.; Kim, J.-C.; Jun, W. Hepatoprotective effects of fermented Curcuma longa L. on carbon tetrachloride-induced oxidative stress in rats. Food Chem. 2014, 151, 148-153. [CrossRef]

21. Zeng, C.; Zhong, P.; Zhao, Y.; Kanchana, K.; Zhang, Y.; Khan, Z.A.; Chakrabarti, S.; Wu, L.; Wang, J.; Liang, G. Curcumin protects hearts from FFA-induced injury by activating Nrf2 and inactivating NF-кB both in vitro and in vivo. J. Mol. Cell. Cardiol. 2015, 79, 1-12. [CrossRef]

22. Ko, M.-J.; Nam, H.-H.; Chung, M.-S. Conversion of 6-gingerol to 6-shogaol in ginger (Zingiber officinale) pulp and peel during subcritical water extraction. Food Chem. 2019, 270, 149-155. [CrossRef]

23. Mahboubi, M. Zingiber officinale Rosc. essential oil, a review on its composition and bioactivity. Clin. Phytoscience 2019, 5, 1-12. [CrossRef] 
24. Ali, H.A.; Mohamed, S.H.; Alharbi, H.F.; Algheshairy, R.M. Synergism between probiotics and herbs to manage type 2 diabetes in rats. Int. J. Pharm. Pharm. Sci. 2020, 12, 26-35. [CrossRef]

25. Kazeem, M.; Akanji, M.; Yakubu, M.; Ashafa, A. Antiglycation and hypolipidemic effects of polyphenols from Zingiber officinale Roscoe (Zingiberaceae) in streptozotocin-induced diabetic rats. Trop. J. Pharm. Res. 2015, 14, 55-61. [CrossRef]

26. Abubakar, I.B.; Malami, I.; Yahaya, Y.; Sule, S.M. A review on the ethnomedicinal uses, phytochemistry and pharmacology of Alpinia officinarum Hance. J. Ethnopharmacol. 2018, 224, 45-62. [CrossRef]

27. Sun, D.-J.; Zhu, L.-J.; Zhao, Y.-Q.; Zhen, Y.-Q.; Zhang, L.; Lin, C.-C.; Chen, L.-X. Diarylheptanoid: A privileged structure in drug discovery. Fitoterapia 2020, 142, 104490. [CrossRef] [PubMed]

28. Zhang, J.; Dou, J.; Zhang, S.; Liang, Q.; Meng, Q. Chemical composition and antioxidant properties of the essential oil and methanol extracts of rhizoma Alpinia officinarum from China in vitro. Afr. J. Biotechnol. 2010, 9, 4414-4421.

29. Raina, A.P.; Verma, S.; Abraham, Z. Volatile constituents of essential oils isolated from Alpinia galanga Willd. (L.) and A. officinarum Hance rhizomes from North East India. J. Essent. Oil Res. 2014, 26, 24-28. [CrossRef]

30. Martinez-Correa, H.A.; Paula, J.T.; Kayano, A.C.A.; Queiroga, C.L.; Magalhães, P.M.; Costa, F.T.; Cabral, F.A. Composition and antimalarial activity of extracts of Curcuma longa L. obtained by a combination of extraction processes using supercritical $\mathrm{CO}_{2}$, ethanol and water as solvents. J. Supercrit. Fluids 2017, 119, 122-129. [CrossRef]

31. Mesomo, M.C.; Corazza, M.L.; Ndiaye, P.M.; Dalla Santa, O.R.; Cardozo, L.; Scheer, A.D.P. Supercritical CO $\mathrm{CO}_{2}$ extracts and essential oil of ginger (Zingiber officinale R.): Chemical composition and antibacterial activity. J. Supercrit. Fluids 2013, 80, 44-49. [CrossRef]

32. Morsy, N.F. A short extraction time of high quality hydrodistilled cardamom (Elettaria cardamomum L. Maton) essential oil using ultrasound as a pretreatment. Ind. Crop. Prod. 2015, 65, 287-292. [CrossRef]

33. Przygodzka, M.; Zielińska, D.; Ciesarová, Z.; Kukurová, K.; Zieliński, H. Comparison of methods for evaluation of the antioxidant capacity and phenolic compounds in common spices. LWT Food Sci. Technol. 2014, 58, 321-326. [CrossRef]

34. Guo, J.-B.; Fan, Y.; Zhang, W.-J.; Wu, H.; Du, L.-M.; Chang, Y.-X. Extraction of gingerols and shogaols from ginger (Zingiber officinale Roscoe) through microwave technique using ionic liquids. J. Food Compos. Anal. 2017, 62, 35-42. [CrossRef]

35. Abu-Orabi, S.T.; Al-Qudah, M.A.; Saleh, N.R.; Bataineh, T.T.; Obeidat, S.M.; Al-Sheraideh, M.S.; Al-Jaber, H.I.; Tashtoush, H.I.; Lahham, J.N. Antioxidant activity of crude extracts and essential oils from flower buds and leaves of Cistus creticus and Cistus salviifolius. Arab. J. Chem. 2020, 13, 6256-6266. [CrossRef]

36. Al-Dhahli, A.S.; Al-Hassani, F.A.; Mohammed Alarjani, K.; Mohamed Yehia, H.; Al Lawati, W.M.; Najmul Hejaz Azmi, S.; Alam Khan, S. Essential oil from the rhizomes of the Saudi and Chinese Zingiber officinale cultivars: Comparison of chemical composition, antibacterial and molecular docking studies. J. King Saud Univ. Sci. 2020, 32, 3343-3350. [CrossRef]

37. Köse, L.P.; Gülçin, I.; Gören, A.C.; Namiesnik, J.; Martinez-Ayala, A.L.; Gorinstein, S. LC-MS/MS analysis, antioxidant and anticholinergic properties of galanga (Alpinia officinarum Hance) rhizomes. Ind. Crop. Prod. 2015, 74, 712-721. [CrossRef]

38. Feng, Y.; Dunshea, F.R.; Suleria, H.A.R. LC-ESI-QTOF/MS characterization of bioactive compounds from black spices and their potential antioxidant activities. J. Food Sci. Technol. 2020, 57, 4671-4687. [CrossRef] [PubMed]

39. Lu, M.; Yuan, B.; Zeng, M.; Chen, J. Antioxidant capacity and major phenolic compounds of spices commonly consumed in China. Food Res. Int. 2011, 44, 530-536. [CrossRef]

40. Elguindy, N.M.; Yacout, G.A.; El Azab, E.F.; Maghraby, H.K. Chemoprotective effect of elettaria cardamomum against chemically induced hepatocellular carcinoma in rats by inhibiting NF- $\mathrm{kB}$, oxidative stress, and activity of ornithine decarboxylase. S. Afr. J. Bot. 2016, 105, 251-258. [CrossRef]

41. Yashin, A.; Yashin, Y.; Xia, X.; Nemzer, B. Antioxidant activity of spices and their impact on human health: A review. Antioxidants 2017, 6, 70. [CrossRef]

42. Singh, G.; Kiran, S.; Marimuthu, P.; Isidorov, V.; Vinogorova, V. Antioxidant and antimicrobial activities of essential oil and various oleoresins ofElettaria cardamomum (seeds and pods). J. Sci. Food Agric. 2007, 88, 280-289. [CrossRef]

43. Kuyumcu Savan, E.; Küçükbay, F.Z. Essential oil composition of elettaria cardamomum maton. J. Appl. Biol. Sci. $2013,7,42-45$.

44. Chowdhury, S.; Kumar, S. Alpha-terpinyl acetate: A natural monoterpenoid from Elettaria cardamomum as multi-target directed ligand in Alzheimer's disease. J. Funct. Foods 2020, 68, 103892. [CrossRef]

45. Jakab, E.; Blazsó, M.; Barta-Rajnai, E.; Babinszki, B.; Sebestyén, Z.; Czégény, Z.; Nicol, J.; Clayton, P.; McAdam, K.; Liu, C. Thermo-oxidative decomposition of lime, bergamot and cardamom essential oils. J. Anal. Appl. Pyrolysis 2018, 134, 552-561. [CrossRef]

46. Kizhakkayil, J.; Thomas, E.; Zachariah, T.; Syamkumar, S.; Sasikumar, B. A comparative quality appraisal of exported cardamoms of India, Sri Lanka and Guatemala. Indian J. Nat. Prod. Resour. 2006, 5, 361-365.

47. Naz, S.; Ilyas, S.; Parveen, Z.; Javed, S. Chemical analysis of essential oils from turmeric (Curcuma longa) rhizome through GC-MS. Asian J. Chem. 2010, 22, 3153-3158.

48. Zhang, L.; Yang, Z.; Chen, F.; Su, P.; Chen, D.; Pan, W.; Fang, Y.; Dong, C.; Zheng, X.; Du, Z. Composition and bioactivity assessment of essential oils of Curcuma longa L. collected in China. Ind. Crop. Prod. 2017, 109, 60-73. [CrossRef]

49. Gounder, D.K.; Lingamallu, J. Comparison of chemical composition and antioxidant potential of volatile oil from fresh, dried and cured turmeric (Curcuma longa) rhizomes. Ind. Crop. Prod. 2012, 38, 124-131. [CrossRef]

50. Mastinu, A.; Bonini, S.; Premoli, M.; Maccarinelli, G.; Mac Sweeney, E.; Zhang, L.; Lucini, L.; Memo, M. Protective effects of Gynostemma pentaphyllum (var. Ginpent) against lipopolysaccharide-induced inflammation and motor alteration in mice. Molecules 2021, 26, 570. [CrossRef] [PubMed] 
51. Dincer, C.; Topuz, A.; Sahin-Nadeem, H.; Özdemir, K.S.; Cam, I.B.; Tontul, I.; Göktürk, R.S.; Ay, S.T. A comparative study on phenolic composition, antioxidant activity and essential oil content of wild and cultivated sage (Salvia fruticosa Miller) as influenced by storage. Ind. Crop. Prod. 2012, 39, 170-176. [CrossRef]

52. Usai, M.; Marchetti, M.; Foddai, M.; Del Caro, A.; Desogus, R.; Sanna, I.; Piga, A. Influence of different stabilizing operations and storage time on the composition of essential oil of thyme (Thymus officinalis L.) and rosemary (Rosmarinus officinalis L.). LWT Food Sci. Technol. 2011, 44, 244-249. [CrossRef]

53. Kumar, A.; Agarwal, K.; Singh, M.; Saxena, A.; Yadav, P.; Maurya, A.K.; Yadav, A.; Tandon, S.; Chanda, D.; Bawankule, D.U. Essential oil from waste leaves of Curcuma longa L. alleviates skin inflammation. Inflammopharmacology 2018, 26, 1245-1255. [CrossRef] [PubMed]

54. Yue, G.G.-L.; Kwok, H.-F.; Lee, J.K.-M.; Jiang, L.; Chan, K.-M.; Cheng, L.; Wong, E.C.-W.; Leung, P.-C.; Fung, K.-P.; Lau, C.B.-S. Novel anti-angiogenic effects of aromatic-turmerone, essential oil isolated from spice turmeric. J. Funct. Foods 2015, 15, 243-253. [CrossRef]

55. Park, S.Y.; Kim, Y.H.; Kim, Y.; Lee, S.J. Aromatic-turmerone attenuates invasion and expression of MMP-9 and COX-2 through inhibition of NF-KB activation in TPA-induced breast cancer cells. J. Cell. Biochem. 2012, 113, 3653-3662. [CrossRef]

56. Camero, M.; Lanave, G.; Catella, C.; Capozza, P.; Gentile, A.; Fracchiolla, G.; Britti, D.; Martella, V.; Buonavoglia, C.; Tempesta, M. Virucidal activity of ginger essential oil against caprine alphaherpesvirus-1. Vet. Microbiol. 2019, 230, 150-155. [CrossRef]

57. Amalraj, A.; Haponiuk, J.T.; Thomas, S.; Gopi, S. Preparation, characterization and antimicrobial activity of polyvinyl alcohol/gum arabic/chitosan composite films incorporated with black pepper essential oil and ginger essential oil. Int. J. Biol. Macromol. 2020, 151, 366-375. [CrossRef] [PubMed]

58. dos Santos Reis, N.; de Santana, N.B.; de Carvalho Tavares, I.M.; Lessa, O.A.; dos Santos, L.R.; Pereira, N.E.; Soares, G.A.; Oliveira, R.A.; Oliveira, J.R.; Franco, M. Enzyme extraction by lab-scale hydrodistillation of ginger essential oil (Zingiber officinale Roscoe): Chromatographic and micromorphological analyses. Ind. Crop. Prod. 2020, 146, 112210. [CrossRef]

59. De Melo, G.A.N.; Grespan, R.; Fonseca, J.P.; Farinha, T.O.; Da Silva, E.L.; Romero, A.L.; Bersani-Amado, C.A.; Cuman, R.K.N. Inhibitory effects of ginger (Zingiber officinale Roscoe) essential oil on leukocyte migration in vivo and in vitro. J. Nat. Med. 2011, 65, 241-246. [CrossRef]

60. Mahomoodally, M.; Aumeeruddy, M.; Rengasamy, K.R.; Roshan, S.; Hammad, S.; Pandohee, J.; Hu, X.; Zengin, G. Ginger and its active compounds in cancer therapy: From folk uses to nano-therapeutic applications. Semin. Cancer Biol. 2019. [CrossRef]

61. Bruchhage, K.-L.; Koennecke, M.; Drenckhan, M.; Plötze-Martin, K.; Pries, R.; Wollenberg, B. 1,8-cineol inhibits the Wnt/ $\beta$-catenin signaling pathway through GSK-3 dephosphorylation in nasal polyps of chronic rhinosinusitis patients. Eur. J. Pharmacol. 2018, 835, 140-146. [CrossRef]

62. Juergens, U.R. Anti-inflammatory properties of the monoterpene 1.8-cineole: Current evidence for co-medication in inflammatory airway diseases. Drug Res. 2014, 64, 638-646. [CrossRef]

63. Zhang, J.; Pan, H.; Chen, Y.; Tanveer, Z.I.; Liu, L.; Cai, Z.; Hong, Y.; Wu, Y. Application of pharmacodynamics-based optimization to the extraction of bioactive compounds from Chansu. Microchem. J. 2020, 159, 105552. [CrossRef]

64. Rajan, M.; Rajkumar, G.; Farias Lima Guedes, T.J.; Chagas Barros, R.G.; Barros, R.G.C.; Narain, N. Performance of different solvents on extraction of bioactive compounds, antioxidant and cytotoxic activities in Phoenix loureiroi Kunth leaves. J. Appl. Res. Med. Aromat. Plants 2020, 17, 100247. [CrossRef]

65. Pimentel-Moral, S.; Borrás-Linares, I.; Lozano-Sánchez, J.; Alañón, M.; Arráez-Román, D.; Segura-Carretero, A. Pressurized GRAS solvents for the green extraction of phenolic compounds from hibiscus sabdariffa calyces. Food Res. Int. 2020, 137, 109466. [CrossRef]

66. Carbone, K.; Macchioni, V.; Petrella, G.; Cicero, D.O. Exploring the potential of microwaves and ultrasounds in the green extraction of bioactive compounds from Humulus lupulus for the food and pharmaceutical industry. Ind. Crop. Prod. 2020, 156, 112888. [CrossRef]

67. Anwer, M.K.; Shakeel, F. Measurement and correlation of solubility of diosmin in four pure solvents and $\beta$-cyclodextrin solution at $298.15 \mathrm{~K}$ to $333.15 \mathrm{~K}$. Chin. J. Chem. Eng. 2015, 23, 812-815. [CrossRef]

68. Suresh, K.; Nangia, A. Curcumin: Pharmaceutical solids as a platform to improve solubility and bioavailability. CrystEngComm 2018, 20, 3277-3296. [CrossRef]

69. Yang, Q.-Q.; Cheng, L.-Z.; Zhang, T.; Yaron, S.; Jiang, H.-X.; Sui, Z.-Q.; Corke, H. Phenolic profiles, antioxidant, and antiproliferative activities of turmeric (Curcuma longa). Ind. Crop. Prod. 2020, 152, 112561. [CrossRef]

70. Hester, F.; Verghese, M.; Sunkara, R.; Willis, S.; Walker, L.T. A Comparison of the antioxidative and anti-diabetic potential of thermally treated garlic, turmeric, and ginger. Food Nutr. Sci. 2019, 10, 207-219. [CrossRef]

71. Avci, G.A.; Avci, E.; Cilak, G.O.; Cehver, S.C. Antimicrobial and antioxidant activities of Zingiber officinale (ginger) and Alpina officinarum (galangal). Hittite J. Sci. Eng. 2020, 7, 45-49. [CrossRef]

72. Ibáñez, M.D.; Blázquez, M.A. Curcuma longa L. rhizome essential oil from extraction to its agri-food applications. A review. Plants 2020, 10, 44. [CrossRef]

73. Sana, S.; Arshad, M.U.; Farhan, S.; Ahmad, R.; Ali, I.; Tabussam, T. Nutritional characterization of cinnamon and turmeric with special reference to their antioxidant profile. Int. J. Biosci. 2019, 15, 178-187.

74. Razboršek, M.I.; Ivanović, M.; Krajnc, P.; Kolar, M. Choline chloride based natural deep eutectic solvents as extraction media for extracting phenolic compounds from chokeberry (Aronia melanocarpe). Molecules 2020, 25, 1619. [CrossRef] 
75. Singleton, V.L.; Rossi, J.A. Colorimetry of total phenolics with phosphomolybdic-phosphotungstic acid reagents. Am. J. Enol. Vitic. 1965, 16, 144-158.

76. Re, R.; Pellegrini, N.; Proteggente, A.; Pannala, A.; Yang, M.; Rice-Evans, C. Antioxidant activity applying an improved ABTS radical cation decolorization assay. Free Radic. Biol. Med. 1999, 26, 1231-1237. [CrossRef]

77. Benzie, I.F.F.; Strain, J.J. The ferric reducing ability of plasma (FRAP) as a measure of "antioxidant power": The FRAP assay. Anal. Biochem. 1996, 239, 70-76. [CrossRef] [PubMed]

78. Morgenstern, A.; Ekholm, A.; Scheewe, P.; Rumpunen, K. Changes in content of major phenolic compounds during leaf development of sea buckthorn (Hippophaë rhamnoides L.). Agric. Food Sci. 2014, 23, 207-219. [CrossRef] 